\title{
SISTEM PAKAR DIAGNOSA GEJALA KECANDUAN GAME ONLINE DENGAN METODE BACKWARD CHAINING
}

\author{
Farhan Hamdallah \\ Program Studi Sistem Informasi, Institut Manajemen Wiyata Indonesia Sukabumi Jawa Barat, \\ Indonesia \\ farhan.hamdallah@imwi.ac.id
}

\begin{abstract}
In the last decade, there have been people whose style of play effects are online. This style of online gamewill be a very middle thing, because this opium could be a husband with no real life, nor cause death. There are suspected cancer victims online games need to consult this problem on. But many factors are pakah to come to pakkes, such as lazy, no time, our timing so cost. Therefore, the system of cancer experts diagnose online games using backward chaining in the hope that can consult with experts do not need to come to the doctor.
\end{abstract}

Keywords: Online Shopping Game Games, Expert System, Chain Retreat

\section{PENDAHULUAN}

Seiring berjalannya waktu, cepatnya perkembangan teknologi informasi menciptakan berbagai kejadian-kejadian menarik yang terjadi di dunia. Pada dekade terakhir ini, konsep kecanduan internet telah berkembang dalam istilah penerimaannya sebagai gangguan kesehatan yang sah yang sering kali membutuhkan pengobatan (Young, 2007). Orang yang kecanduan internet mengalami kesulitan dalam penggunaannya, sehingga individu tersebut bisa lupa waktu terhadap aktivitas-aktivitas lain sehingga dapat membahayakan terhadap hubungan manusia di dunia nyata, dan aktivitas produktifnya. Sudah banyak solusi diberikan untuk menangani individu yang mengalami kecanduan internet, seperti rumah sakit dan klinik dengan layanan rawat jalan untuk kecanduan internet, pusat rehabilitasi kecanduan internet, dan juga komunitaskomunitas relawan.

Berbagai studi dan penelitian tentang kecanduan internet telah di lakukan di berbagai penjuru dunia seperti di negara Pakistan (Suhail \& Bargees, 2006), Italia
(Ferraro, Caci, D'amico, \& Blasi, 2006), dan Republik Ceko (Simkova \& Cincera, 2004). Dari studi tersebut dapat di simpulkan bahwa konsep kecanduan internet ini sudah menyebar luas di seluruh dunia.

Selain kecanduan internet, kecanduan game online juga menjadi masalah yang sangat serius yang terjadi di seluruh dunia. Bermain game online yang berlebihan di katakan sebagai salah satu sub tipe spesifik dalam kecanduan internet (Block, 2008). Sama seperti kecanduan internet, kecanduan game online ini lebih cenderung pada media game yang terhubung ke internet, sehingga pemain di seluruh dunia dapat terhubung dalam 1 platform untuk bermain dan bersosialisasi bersama layaknya seperti di dunia nyata. Salah satu kasus yang disayangkan yang terjadi adalah seorang pemuda berumur 28 tahun dari negara Korea Selatan meninggal karena bermain game Starcraft selama 50 jam tanpa berhenti (BBC, 2005).

Menurut (Young, 2007) tentang tanda tingkatan peringatan seseorang mengalami kecanduan game online adalah: 
1) Pemain keasyikan terhadap game onlinenya

Pada tahap ini pemain akan lebih mementingkan bermain game online dibanding dengan tugas-tugas sekolah, belajar tentang pelajaran sekolah sampai pergi ke sekolah. Pemain akan fokus terhadap game onlinenya.

2) Pemain Berbohong atau menyembunyikan terhadap aktivitas game onlinenya

Pemain akan lupa untuk makan, lupa tidur, bahkan lupa untuk mandi. Pemain akan berbohong kepada keluarga dan teman tentang apa yang Pemain lakukan di depan komputer, seperti berbohong bahwa Pemain sedang mengerjakan tugas rumah nya di depan komputer

3) Pemain tidak memiliki ketertarikan terhadap aktivitas lain.

Semakin kecanduan, maka semakin kurang tertarik dengan hobi atau aktivitas yang lain.

4) Social withdrawal atau penarikan sosial

Yaitu kondisi dimana seseorang yang pernah menjadi orang yang bersosial menjadi sebaliknya dan lebih cenderung mementingkan bersosial di game online di banding di kehidupan nyata.

5) Sikap defensif dan amarah

Karena kecanduannya, pemain lebih cenderung defensif akan kebutuhan dalam pemenuhan bermain game nya dan akan marah jika tidak bermain. Orang tua yang membatasi anaknya untuk bermain game menceritakan bahwa anak mereka menjadi marah, sensitif dan bahkan main pukul atau kekerasan.

6) Psychological withdrawal

Pemain yang tidak mendapat akses untuk bermain game akan mengalami kecemasan atau depresi, cepat marah.

7) Menggunakan game sebagai pelarian
Pemain akan berpikir dunia game online menjadi pelarian psychologic. Game menjadikannya aman terhadap masalah kehidupan nyata. Semakin Pemain bermain game online dengan kemajuan lebih tinggi, Pemain akan merasakan kesenangan dalam pencapaian, lebih di terima dan merasakan lebih baik terhadap dirinya sendiri dalam dunia game dibanding dirinya sendiri di kehidupan nyata.

8) Bermain berkelanjutan terlepas dari konsekuensinya.

Di tingkat ini, pemain tidak memedulikan kehidupannya sendiri, maka Pemain cenderung akan gagal di sekolah, hilangnya beasiswa, putus dengan pacar, mengabaikan kebersihannya, kehilangan pekerjaan sampai kehilangan hubungan dengan pasangan suami/istri hanya karena lebih mementingkan game dan loyal pada game.

Seseorang yang diduga mengalami gejala kecanduan game online perlu mengonsultasikan permasalahannya ini pada psikiater. Namun banyak faktor yang menghambat seseorang untuk datang ke psikiater, seperti malas, tidak ada waktu, antrean pasien sampai biaya.

Untuk solusi dari permasalahan tersebut, diperlukan sebuah sistem yang menggantikan psikiater. Sistem tersebut adalah sistem pakar. Yang dimaksud dengan pakar adalah seseorang yang memiliki keahlian khusus dalam menyelesaikan masalah yang tidak mampu diselesaikan oleh orang awam. Sistem pakar adalah cabang dari kecerdasan buatan terapan, dan dikembangkan oleh komunitas kecerdasan buatan pada pertengahan 1960-an. Ide dasar di balik sistem pakar hanyalah 
bahwa keahlian, yang merupakan sekumpulan luas dari pengetahuan, ditransfer dari manusia ke komputer (Balci \& Smith, 1986).

$$
\text { Pada dasarnya sistem pakar }
$$
diterapkan untuk mendukung kegiatan pemecahan masalah. Beberapa kegiatan pemecahan masalah yang dimaksud adalah (Lestari, 2012):

- Interpretasi. Membuat kesimpulan atau deskripsi dari sekumpulan data mentah. Pengambilan keputusan berdasarkan pengamatan, termasuk pengenalan suara, analisis gambar, interpretasi sinyal, dll.

- Prediksi. Memproyeksikan kemungkinan konsekuensi dari situasi tertentu. Contoh: prediksi demografi, prediksi ekonomi, dll.

- Diagnosis. Menentukan penyebab kerusakan dalam situasi kompleks berdasarkan gejala yang diamati dari diagnosis diagnosis medis, elektronik, mekanis, dll.

- Perancangan (desain). Menentukan konfigurasi komponen sistem yang sesuai untuk tujuan kinerja tertentu yang memenuhi batasan tertentu. Contoh: perancangan layout sirkuit, bangunan.

- Perencanaan. Merencanakan serangkaian tindakan yang akan dapat mencapai sejumlah tujuan dengan kondisi awal tertentu. Contoh: perencanaan keuangan, militer, dll.

- Monitoring. Membandingkan hasil observasi dengan kondisi yang diharapkan. Contoh: computer aided monitoring system.

- Debugging. Menentukan dan menginterpretasikan cara-cara untuk mengatasi malfungsi. Contoh: meresepkan obat untuk melawan kegagalan.

- Instruksi. Mendeteksi dan memperbaiki kekurangan dalam memahami domain subjek. Contoh: lakukan instruksi untuk diagnosis dan debugging.

- Kontrol. Mengatur perilaku lingkungan yang kompleks. Contoh: mengendalikan interpretasi, prediksi, peningkatan dan pemantauan perilaku sistem.

Backward Chaining adalah suatu teknik pelacakan yang dimulai dari sekumpulan kesimpulan, lalu hipotesis yang diinginkan, kemudian dengan mempergunakan kaidah-kaidah yang ada akan dicari sejumlah besar kondisi awal fakta-fakta yang mendukung kaidah-kaidah tersebut. Pencocokan fakta atau pernyataan dimulai dari bagian sebelah kanan (Syafrizal \& A. H. Setyaningrum, 2015).

\section{METODE PENELITIAN}

Tahapan penelitian yang dilakukan pada penelitian ini dijelaskan pada tahaptahap berikut :

\section{1) Identifikasi Masalah}

Tahap ini melakukan perumusan masalah terhadap objek penelitian dengan tujuan menentukan masalah apa yang terjadi dan menentukan batasan dari permasalahan yang akan di teliti.

\section{2) Studi Literatur}

Tahap ini melakukan pembelajaran literatur yang berhubungan dengan permasalahan yang nantinya akan berguna untuk menyelesaikan penelitian.

\section{3) Membangun Basis Pengetahuan}

Tahap membangun basis pengetahuan ini dibagi menjadi 2 tahapan. Pertama adalah tahapan akuisisi pengetahuan, selanjutnya adalah tahap 
representasi pengetahuan. Akuisisi pengetahuan merupakan tahapan untuk mendapatkan pengetahuan tentang permasalahan yang sedang di bahas dan digunakan dalam pengembangan. Setelah itu dilakukan representasi data ke dalam basis pengetahuan dan basis aturan yang kemudian di buat program, pengorganisasian, dan digambarkan dalam bentuk tabel perkondisian keputusan sehingga menjadi bentuk yang sistematis

4) Mendesain Sistem

Tahapan selanjutnya adalah mendesain sistem. Desain sistem ini bertujuan untuk menjadi acuan pada rancang bangun sistem

5) Pembangunan Sistem

Tahapan ini adalah tahapan realisasi sistem berdasarkan yang sudah di rancang. Tahap ini melakukan programming dengan program komputer yang nantinya hasilnya akan menjadi sebuah aplikasi yang dapat dipakai untuk orang yang membutuhkan

6) Pengujian Sistem

Sistem yang dibuat nantinya perlu di uji kesesuaiannya sebelum dapat di deploy di server dan digunakan oleh orang yang membutuhkan

\section{HASIL DAN PEMBAHASAN}

\section{1) Akuisisi Pengetahuan}

Akuisisi pengetahuan merupakan proses pengumpulan informasi dari sumber-sumber yang tersedia yang bisa berupa kepakaran seorang ahli. Data yang diperoleh pada penelitian ini merupakan dari hasil literatur dari penelitian-penelitian sebelumnya tentang kecanduan game online.

2) Representasi Pengetahuan

Setelah pengetahuan berhasil di akuisisi, pengetahuan tersebut selanjutnya akan di representasikan dalam bentuk-bentuk yang dikenali oleh sistem komputer

Berikut adalah pengetahuan tentang gejala kecanduan game online yang telah di kodekan yang dijelaskan pada tabel berikut :

Tabel 1

Tabel Level Kecanduan

\begin{tabular}{lll}
\hline Level & \multicolumn{1}{c}{$\begin{array}{c}\text { Nama Level } \\
\text { Kecanduan }\end{array}$} & ID Gejala \\
\hline 1 & $\begin{array}{l}\text { Pemain keasyikan } \\
\text { terhadap game onlinenya }\end{array}$ & LK1 \\
\hline 2 & $\begin{array}{l}\text { Pemain Berbohong atau } \\
\text { menyembunyikan } \\
\text { terhadap aktivitas game }\end{array}$ & LK2 \\
& $\begin{array}{l}\text { onlinenya } \\
\text { Pemain tidak memiliki }\end{array}$ & LK3 \\
\hline 3 & $\begin{array}{l}\text { ketertarikan terhadap } \\
\text { aktivitas lain. }\end{array}$ & \\
\hline 4 & $\begin{array}{l}\text { Social withdrawal } \\
\text { Sikap defensif dan } \\
\text { amarah LK5 }\end{array}$ & LK4 \\
\hline 5 & $\begin{array}{l}\text { Psychological } \\
\text { withdrawal }\end{array}$ & LK6 \\
\hline 6 & $\begin{array}{l}\text { Menggunakan game } \\
\text { sebagai pelarian }\end{array}$ & LK7 \\
\hline 8 & $\begin{array}{l}\text { Bermain berkelanjutan } \\
\text { terlepas LK8 } \\
\text { konsekuensinya }\end{array}$ & dari \\
\hline
\end{tabular}

Tabel 2

Gejala Kecanduan Game online

\begin{tabular}{lll}
\hline No & \multicolumn{1}{c}{ Gejala } & ID Gejala \\
\hline 1 & Menyukai Game online & $\mathrm{G} 01$ \\
\hline 2 & $\begin{array}{l}\text { Game online di anggap } \\
\text { mengasyikkan }\end{array}$ & $\mathrm{G} 02$ \\
\hline 3 & $\begin{array}{l}\text { Melakukan bohong karena } \\
\text { bermain game online }\end{array}$ & $\mathrm{G} 03$ \\
\hline 4 & $\begin{array}{l}\text { Menyembunyikan bahwa } \\
\text { pemain selalu bermain } \\
\text { game online }\end{array}$ \\
\hline 5 & $\begin{array}{l}\text { Sangat menyukai aktivitas } \\
\text { bermain game online }\end{array}$ \\
\hline 6 & $\begin{array}{l}\text { Menganggap game online } \\
\text { lebih G06 } \\
\text { daripada aktivitas lain }\end{array}$ \\
\hline 7 & Menghilang dari sosial & $\mathrm{G} 07$ \\
\hline 8 & $\begin{array}{l}\text { Menganggap bersosial di } \\
\text { game online lebih penting } \\
\text { dari bersosial di kehidupan } \\
\text { nyata }\end{array}$ \\
\hline 9 & Marah jika melarang untuk $\mathrm{G} 09$ \\
\hline
\end{tabular}




\begin{tabular}{lll}
\hline No & \multicolumn{1}{c}{ Gejala } & ID Gejala \\
\hline $\begin{array}{l}\text { berhenti bermain game } \\
\text { online }\end{array}$ & \\
\hline 10 & $\begin{array}{l}\text { Cenderung menjadi } \\
\text { defensif terhadap game } \\
\text { online }\end{array}$ \\
\hline 11 & $\begin{array}{l}\text { Menjadi cemas jika tidak G11 } \\
\text { bermain game online }\end{array}$ \\
\hline 12 & $\begin{array}{l}\text { Menjadi depresi jika tidak G12 } \\
\text { bermain game online }\end{array}$ \\
\hline 13 & $\begin{array}{l}\text { Menjadikan game online } \\
\text { sebagai pelarian }\end{array}$ \\
\hline 14 & $\begin{array}{l}\text { Tidak memedulikan G14 } \\
\text { terhadap kehidupan nyata, } \\
\text { hanya memedulikan game } \\
\text { online }\end{array}$ \\
\hline
\end{tabular}

Tabel 3

Aturan/Perkondisian Kecanduan Game

\begin{tabular}{lll}
\multicolumn{1}{c}{ online } \\
\hline No & \multicolumn{1}{c}{ IF } & \multicolumn{1}{c}{ THEN } \\
\hline 1 & G01 True AND G02 True & LK1 \\
\hline 2 & $\begin{array}{l}\text { LK1 True And G03 True } \\
\text { And G04 True }\end{array}$ & LK2 \\
\hline 3 & $\begin{array}{l}\text { LK2 True And G05 True } \\
\text { And G06 True }\end{array}$ & LK3 \\
\hline 4 & $\begin{array}{l}\text { LK3 True And G07 True } \\
\text { And G08 True }\end{array}$ & LK4 \\
\hline 5 & $\begin{array}{l}\text { LK4 True And G09 True } \\
\text { And G10 True }\end{array}$ & LK5 \\
\hline 6 & $\begin{array}{l}\text { LK5 True And G11 True } \\
\text { And G12 True }\end{array}$ & LK6 \\
\hline 7 & LK6 True And G13 True & LK7 \\
\hline 8 & LK7 True And G14 True & LK8 \\
\hline
\end{tabular}

\section{3) Desain Sistem}

Berikut merupakan desain sistem yang akan di bangun, pada penelitian ini disampaikan dengan tools Use Case Diagram. Use Case Diagram digunakan untuk mendefinisikan aksi-aksi dan kolaborasi yang dilakukan oleh pengguna terhadap sistem. Dibawah ini merupakan Use Case Sistem Pakar Diagnosa Kecanduan Game online:

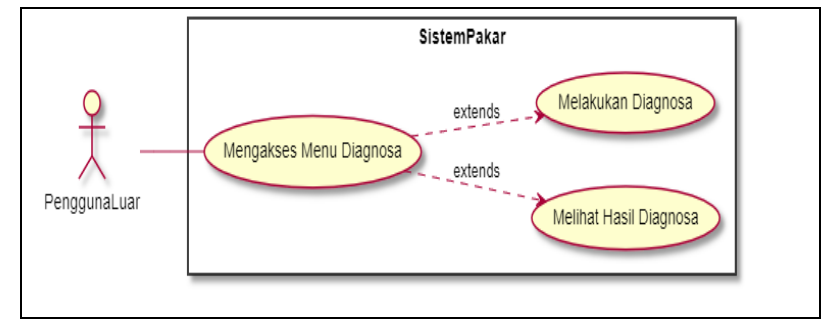

\section{Gambar 1}

Desain Use Case Sistem Pakar Diagnosa Kecanduan Game online

\section{4) Pembangunan Sistem}

Dibawah ini merupakan hasil pembangunan dari aplikasi web sistem pakar diagnosa gejala kecanduan game online:

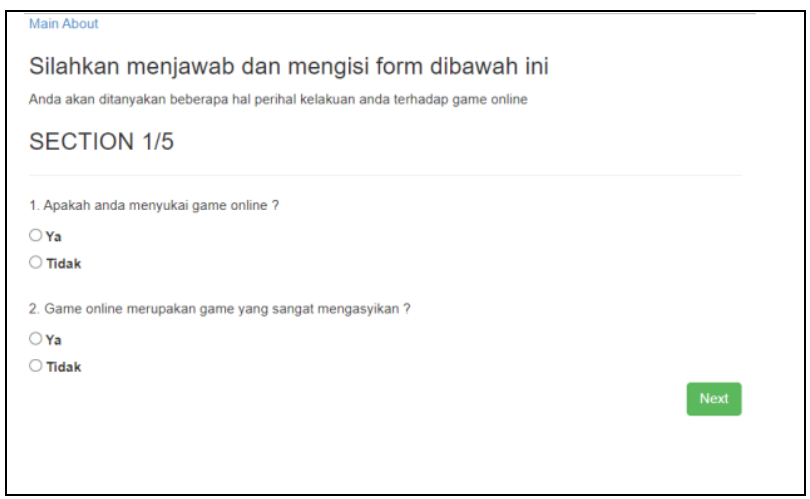

Gambar 2

Halaman Form untuk menilai gejala LKGO1

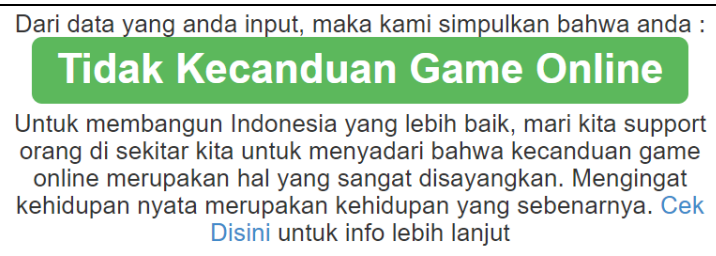

Untuk membangun Indonesia yang lebih baik, mari kita support orang di sekitar kita untuk menyadari bahwa kecanduan game online merupakan hal yang sangat disayangkan. Mengingat kehidupan nyata merupakan kehidupan yang sebenarnya. Cek Disini untuk info lebih lanjut

\section{Gambar 3}

\section{5) Pengujian Sistem}

\section{Halaman Hasil Konsultasi}

Tahap selanjutnya adalah pengujian sistem. Sistem diuji sesuai dengan rules-rules yang telah dibuat. Dibawah ini merupakan hasil dari pengujian sistem pakar diagnosa kecanduan game online: 
Tabel 4

Hasil pengujian sistem

\begin{tabular}{|c|c|c|c|}
\hline No & $\begin{array}{l}\text { Nama } \\
\text { Pengujian }\end{array}$ & $\begin{array}{l}\text { Hasil yang } \\
\text { diharapkan }\end{array}$ & $\begin{array}{l}\text { Hasil yang } \\
\text { didapatkan }\end{array}$ \\
\hline 1 & $\begin{array}{l}\text { Menginput } \\
\text { data sebagai } \\
\text { user yang } \\
\text { mengalami } \\
\text { level gejala } \\
\text { kecanduan } \\
\text { LK1 }\end{array}$ & $\begin{array}{l}\text { Sistem } \\
\text { menampilkan } \\
\text { hasil bahwa } \\
\text { user } \\
\text { mengalami } \\
\text { level gejala } \\
\text { kecanduan } \\
\text { LK1 }\end{array}$ & $\begin{array}{l}\text { Sistem } \\
\text { menampilkan } \\
\text { hasil bahwa } \\
\text { user } \\
\text { mengalami } \\
\text { level gejala } \\
\text { kecanduan } \\
\text { LK1 }\end{array}$ \\
\hline 2 & $\begin{array}{l}\text { Menginput } \\
\text { data sebagai } \\
\text { user yang } \\
\text { mengalami } \\
\text { level gejala } \\
\text { kecanduan } \\
\text { LK2 }\end{array}$ & $\begin{array}{l}\text { Sistem } \\
\text { menampilkan } \\
\text { hasil bahwa } \\
\text { user } \\
\text { mengalami } \\
\text { level gejala } \\
\text { kecanduan } \\
\text { LK2 }\end{array}$ & $\begin{array}{l}\text { Sistem } \\
\text { menampilkan } \\
\text { hasil bahwa } \\
\text { user } \\
\text { mengalami } \\
\text { level gejala } \\
\text { kecanduan } \\
\text { LK2 }\end{array}$ \\
\hline 3 & $\begin{array}{l}\text { Menginput } \\
\text { data sebagai } \\
\text { user yang } \\
\text { mengalami } \\
\text { level gejala } \\
\text { kecanduan } \\
\text { LK3 }\end{array}$ & $\begin{array}{l}\text { Sistem } \\
\text { menampilkan } \\
\text { hasil bahwa } \\
\text { user } \\
\text { mengalami } \\
\text { level gejala } \\
\text { kecanduan } \\
\text { LK3 }\end{array}$ & $\begin{array}{l}\text { Sistem } \\
\text { menampilkan } \\
\text { hasil bahwa } \\
\text { user } \\
\text { mengalami } \\
\text { level gejala } \\
\text { kecanduan } \\
\text { LK3 }\end{array}$ \\
\hline 4 & $\begin{array}{l}\text { Menginput } \\
\text { data sebagai } \\
\text { user yang } \\
\text { mengalami } \\
\text { level gejala } \\
\text { kecanduan } \\
\text { LK4 }\end{array}$ & $\begin{array}{l}\text { Sistem } \\
\text { menampilkan } \\
\text { hasil bahwa } \\
\text { user } \\
\text { mengalami } \\
\text { level gejala } \\
\text { kecanduan } \\
\text { LK4 }\end{array}$ & $\begin{array}{l}\text { Sistem } \\
\text { menampilkan } \\
\text { hasil bahwa } \\
\text { user } \\
\text { mengalami } \\
\text { level gejala } \\
\text { kecanduan } \\
\text { LK4 }\end{array}$ \\
\hline 5 & $\begin{array}{l}\text { Menginput } \\
\text { data sebagai } \\
\text { user yang } \\
\text { mengalami } \\
\text { level gejala } \\
\text { kecanduan } \\
\text { LK5 }\end{array}$ & $\begin{array}{l}\text { Sistem } \\
\text { menampilkan } \\
\text { hasil bahwa } \\
\text { user } \\
\text { mengalami } \\
\text { level gejala } \\
\text { kecanduan } \\
\text { LK5 }\end{array}$ & $\begin{array}{l}\text { Sistem } \\
\text { menampilkan } \\
\text { hasil bahwa } \\
\text { user } \\
\text { mengalami } \\
\text { level gejala } \\
\text { kecanduan } \\
\text { LK5 }\end{array}$ \\
\hline 6 & $\begin{array}{l}\text { Menginput } \\
\text { data sebagai } \\
\text { user yang } \\
\text { mengalami } \\
\text { level gejala } \\
\text { kecanduan } \\
\text { LK6 }\end{array}$ & $\begin{array}{l}\text { Sistem } \\
\text { menampilkan } \\
\text { hasil bahwa } \\
\text { user } \\
\text { mengalami } \\
\text { level gejala } \\
\text { kecanduan } \\
\text { LK6 }\end{array}$ & $\begin{array}{l}\text { Sistem } \\
\text { menampilkan } \\
\text { hasil bahwa } \\
\text { user } \\
\text { mengalami } \\
\text { level gejala } \\
\text { kecanduan } \\
\text { LK6 }\end{array}$ \\
\hline 7 & $\begin{array}{l}\text { Menginput } \\
\text { data sebagai } \\
\text { user yang } \\
\text { mengalami }\end{array}$ & $\begin{array}{l}\text { Sistem } \\
\text { menampilkan } \\
\text { hasil bahwa } \\
\text { user }\end{array}$ & $\begin{array}{l}\text { Sistem } \\
\text { menampilkan } \\
\text { hasil bahwa } \\
\text { user }\end{array}$ \\
\hline
\end{tabular}

\begin{tabular}{|c|c|c|c|}
\hline No & $\begin{array}{l}\text { Nama } \\
\text { Pengujian }\end{array}$ & $\begin{array}{l}\text { Hasil yang } \\
\text { diharapkan }\end{array}$ & $\begin{array}{l}\text { Hasil yang } \\
\text { didapatkan }\end{array}$ \\
\hline & $\begin{array}{l}\text { level gejala } \\
\text { kecanduan } \\
\text { LK7 }\end{array}$ & $\begin{array}{l}\text { mengalami } \\
\text { level gejala } \\
\text { kecanduan } \\
\text { LK7 }\end{array}$ & $\begin{array}{l}\text { mengalami } \\
\text { level gejala } \\
\text { kecanduan } \\
\text { LK7 }\end{array}$ \\
\hline 8 & $\begin{array}{l}\text { Menginput } \\
\text { data sebagai } \\
\text { user yang } \\
\text { mengalami } \\
\text { level gejala } \\
\text { kecanduan } \\
\text { LK8 }\end{array}$ & $\begin{array}{l}\text { Sistem } \\
\text { menampilkan } \\
\text { hasil bahwa } \\
\text { user } \\
\text { mengalami } \\
\text { level gejala } \\
\text { kecanduan } \\
\text { LK8 }\end{array}$ & $\begin{array}{l}\text { Sistem } \\
\text { menampilkan } \\
\text { hasil bahwa } \\
\text { user } \\
\text { mengalami } \\
\text { level gejala } \\
\text { kecanduan } \\
\text { LK8 }\end{array}$ \\
\hline
\end{tabular}

\section{Kesimpulan}

Kesimpulan yang dapat diambil dari penelitian yang telah dilakukan ini adalah:

1. Telah dirancang dan dibangun sistem pakar diagnosa kecanduan game online berbasis web yang harapannya dapat menjadi solusi alternatif pengguna luar terhadap masalah-masalah untuk datang ke psikolog

2. Ditemukan bahwa ada 8 level kecanduan seseorang terhadap game online, yaitu pemain keasyikan terhadap game onlinenya, pemain berbohong dan menyembunyikan terhadap aktivitas game onlinenya, pemain tidak memiliki ketertarikan terhadap aktivitas lain, social withdrawal, sikap defensif dan amarah, psychological withdrawal, menggunakan game sebagai pelarian dan bermain berkelanjutan terlepas dari konsekuensinya.

\section{Saran}

Adapun saran-saran dari penelitian ini untuk dijadikan penelitian yang dapat dilakukan yaitu menganalisis dan merekomendasikan perbaikan di UI/UX yang dikhususkan untuk pengguna yang memiliki gejala kecanduan game online. 


\section{DAFTAR PUSTAKA}

Balci, O. \& Smith, E., 1986. Validation of expert system performance.

BBC, 2005. BBC News. [Online] Available at: http://news.bbc.co.uk/2/hi/technology /4137782.stm [Diakses 74 2021].

Block, Jerald J. (2008). Issues for DSM-V: Internet addiction. Am Psychiatric Assoc.

Ferraro, Giovanni, Caci, Barbara, D'amico, Antonella, \& Blasi, Marie Di. (2006). Internet addiction disorder: an Italian study. CyberPsychology \& Behavior, 10(2), 170-175.

Lestari, D. (2012). Definisi sistem pakar. Arsip Jurnal Teknik Informatika UMMI.

Septuaginta, A., \& Abidin, B. J. Z. (2020). Perancangan User Interface Website Institut Manajemen Wiyata Indonesia. Cakrawala, 3(1), 75-80.

Simkova, Barbora, \& Cincera, Jan. (2004). Internet addiction disorder and chatting in the Czech Republic. CyberPsychology \& Behavior, 7(5), 536-539.

Suhail, Kausar, \& Bargees, Zobia. (2006). Effects of excessive Internet use on undergraduate students in Pakistan. CyberPsychology \& Behavior, 9(3), 297-307.

Syafrizal, D. P. \& A. H. Setyaningrum, \&. K. H., 2015. Penggunaan Metode Forward Chaining Pada Aplikasi Deteksi Pendingin Reaktor Serba Guna. PrsgBatan, pp. 1-9.

Young, K., 2007. Cognitive-behavioral therapy with Internet addicts: Treatment outcomes and implications. s.l.:s.n.

Abidin, Budi Zaenal, and Zainil Abidin. "Analisa dan Perancangan Sistem
Rekrutmen Dosen Berbasis Web." Syntax Literate; Jurnal Ilmiah Indonesia 5.7 (2020): 262-273. 